\title{
Between Ebola epidemics and Boko-Haram insurgency: Media agenda transition interplay
}

\author{
Lateef Adelakun ${ }^{1, *}$, and Hamedi Adnan ${ }^{2}$ \\ ${ }^{1} \mathrm{PhD}$ Student, Department of Media Studies, University of Malaya, Malaysia \\ ${ }^{2}$ HOD, Department of Media Studies, University of Malaya, Malaysia
}

\begin{abstract}
The menace of Ebola outbreak coincidence with Boko haram insurgency left not only the policy formulators in disarray but also rocked the media with indecision on which to prioritize. Media set agenda on the most important issue or on an issue the media want to make important but the dissection of which suppresses the other when two issues are keenly considered of public interests fames discussions on agenda transition. Ebola epidemic rocked Nigeria at a time when media coverage of Boko Haram insurgency was at its climax, setting double battles for government to fight and for media to frame as public agenda. Content analyses of two Nigerian newspapers between June and December, 2014, explained the fade-in and fade-out strategy that the media employed to set, sustain and shuttle agenda front-and-back on the issues. The media interest to guide the audience decisions on the duo (health and security challenges) also explained the indispensability of media agenda role and the priority leverage among issues.
\end{abstract}

\section{Introduction}

Terrorist activities attributed to Jamā'at Ahl as-Sunnah lid-Da'wah wa'l-Jihād popularly known as 'Boko Haram" in 2009 just after the 'extrajudicial' killing of its leader, Mohammed Yusuf by the Nigerian police did not only make the ideology of the group known but also marked the beginning of the long record of insurgency Nigeria has ever fought. Boko-Haram, (often translated as "Western culture is heresy"), the name most often used to refer to the group, which captured one of its ideologies, has become a sobriquet for terrorism in the media across the globe. Religious antecedent of the group's ideology, fuelled by political aberration and rivalry upon which Nigerian government failed to nail it in the bud aggrandised terrorism in Nigeria. As terrorism started gathering momentum especially since 2011, it structurally became a common news focus fading away the public attention on other major concerned issues. Since 2011, issues on Boko Haram insurgency have been consistently enjoying priority on the media agenda. Mass media, particularly newspapers explored the many news angles through which the issues surface and resurface to keep the public interest aglow of the saga until Ebola Virus Disease (EVD) broke out in Nigeria in 2014 [1].

EVD came to Nigeria at the time two major issues (Political Campaign and rivalry that precipitated 2015 general election and the incessant and uncurtail Boko-Haram insurgency) had wrapped up both media and public attentions. EVD in Nigeria, though surfaced at the time the insurgency was at the peak of media agenda competed for media saliency. Then, 'how does a new issue creep into the height of media agenda and fade away or be at neck-on-neck with the one already enjoying media saliency?', which is the central question addressed by this work deepens explanation on saliency transfer among issues upon which media/public agenda are set.

Making an issue salient among the most important issues competing for limited audience attention though is regarded as sole responsibility of the media, the expectation is that gravity of the issues should remain the major criteria upon which the media decision to set agenda is based. Going by the trends of the topmost issues in the mid-2014, Boko Haram Insurgency and Ebola Attack topped the media agenda list. Media could have used other parameters to decide which of the issues should be more emphasised than the other upon which the agenda was set for the public. But our concern in this study is not only to verify which of the competing issues at the time was made salient in the media but also to explain which agenda-setting strategy did the newspapers employed to sustain the saliency of the prioritised between the issues.

\footnotetext{
* Corresponding author: delak058@yahoo.co.uk
} 


\section{Literature Review}

Vinson [2], in his review of Boydstun [3] work related to media patterns of coverage that determine choices of issue upon which media agenda is built, emphasised on the two approaches itemised. The approaches, according to Vinson (pg. 761) - "alarm mode, where some event suddenly calls reporters' attention to an issue and the patrol mode, where the media regularly report on certain issue in a more traditional watchdog role" though do not totally explain reasons why media make some issue salient at the expense of others, both add up to criteria upon which the media decision on what issue it consider the most important for the public consumption. Having established that the media cannot give the same proportion of attention to all issues, the media decision on which should be made more significant is moderated by plethora of factors among which the need to meet the nature of market information demand (what issue interest the audience the most) speaks volumes. The consideration of the factors also tells much on how long an issue enjoy media saliency (how long it remains on the top rung of media agenda ladder) and at what point does a new or another issue fades away the one enjoying media saliency. Martin [4], while reviewing the same work, pays attention to discusses, which Boydstun described as momentum, skew and explosion as indices that determine while some issues easily getting on the media agenda and some others don't. Martin's satisfaction with the generalisation test of the Boydstun's alarm/patrol hybrid model that explain reasons some issue find a way into media agenda can explain while EVD, despite its short period in Nigeria competed with Boko-Haram issue in the race towards forming the media agenda.

This description in actual sense makes the theory relevant in addressing the central obligation of the media to manage news in favour of societal development. Mustapha [5], agrees that the application of agenda-setting theory cut across various issues. Coleman, McCombs [6], also confirm that researchers have adapted the theory to discuss and understand number of issues. But the concern is how layers of agenda setting influence the public agenda and decisions and how do the media and public agenda shift from an issue to another most especially when issues saliency are competing for audience attentions and public concerns. Whether first level or second level of agenda-setting or even "agenda-building" [7] and "agenda melding" [8], the central focus, which is salient shift is a confirmation of media involvement at all levels.

The media agenda-setting concern of 'What the audience think about' could be regarded as the primary stage of the media influential might on audience. As the inequitable treatment of myriad news items competing for audience attentions elevate audience interests in a news item above others, it paves ways for other media influential concepts such as framing and priming to germane. It saves and redefines media framing concern of 'how to think about all issue' to a more succinct and manageable concept, 'how to think about the 'most important issue'.

\subsection{Agenda Setting Transition}

At the time Ebola broke out in Nigeria, there were other issues of perhaps equal importance competing for audience attentions such as Boko-Haram insurgency, which was then at its tensed stage, and the issue of political transition, which was hanging loosely as hyper tension general election (first of its kind, in which the opposition unseat the ruling party) drawn near at the time. Making choice out of the competing news items upon which the media agenda is set is a media task that depends on certain number of influences ranging from media perception of reality and the nature of media environment including audience wariness to the happenings around them. Audience wariness (how active the audience) is an important factor that segregate between what the media considered important and what the audience assumed essential [9], a dichotomy that leads to 'transfer of salience'.

Shifting audience attentions from what they earlier considered most important in relation to the earlier media positioning of issues reported is another area where the essence of media agenda is felt [10]. This requires that the media proportionately reduce the saliency (the amount of attention and prominence given to issues) of one issue to give in to new one that requires public attention. Prior to EVD outbreak in Nigeria, Boko Haram insurgency was the main agenda (both media and public), which went as far as influencing international perception, assessment and definition of peace in Nigeria upon which the country foreign policies depend. Despite the worrisome nature of the insurgency, media repositioning of issues (Agenda-Shifting) subdue its saliency to allow EVD crept to the top of agenda [11].

However, shifting agenda from one issue to another can be discussed under two faces - full and partial. A full shift of media agenda (which could be regarded as Agenda-setting transfer) occurs when there is over domination of public attentions on new issue as a result of the total shift in the saliency that the previous issue enjoyed in the media. It results in the assumption that the old issue has rather been over-flogged or it has been concluded and there is no fresh angle to the issue, which may press for public attention or debate. In this kind scenario, new issue of media agenda benefits immensely as more attention is given to it from both media and public. EVD outbreak did not enjoy the kind of agenda shift as other issues of proportionate importance competed for the media saliency as well as public attentions. The case of EVD outbreak fits in to Partial agenda shifting (Agenda-setting shift) in which new issue competes with the old media agenda for media saliency as well as public attention. Though the main agenda may be shifted to the new issue, old issues are not totally wiped off but rather subjected to saliency reduction as well as shortfall in the public attentions. As EVD outbreak became the media and public agenda, the importance attached to Boko Haram insurgency and general election, which were at the time burning issues subsided.

Studies [12-14] have used Agenda-setting transfer to depict how media agenda translate to what the audience consider as the most important issue, a concept used to describe issue salience in what is considered first-level agenda- 
setting. The concept mostly explains how "issue attributes salient in the media were functioning as significant dimensions of issue evaluation among audience member" [12]. The operational assumption of agenda-setting transfer in this work diversifies into the transition from one issue salience to another rather than movement of the salience within the agenda players (media and audience).

Most often, the rate at which an issue fade-in to allow the agenda set on another issue predominantly depends on the differences in the gravity of both issues as well as the longevity of the period the earlier issue remains on top of the media agenda based on the issue lifespan [15]. The lifespan of an issue includes the period from issue conception (perhaps, when first reported in the media) until salience is built around it to enjoy public attention and recognition (public agenda). Agenda climax sets in when such issue becomes the central focus of both the media and the public and remains the priority on the ladder of individual concerns. Fresh angles to the issue usually dictate how long it remains at the climax of media and public agenda ladder. Mass Media capitalise on the fresh angles to prolong the salient period an issue enjoys from the public. Until a new issue of predominant importance occurs to facilitate 'return to scale' of the previous issue, public attentions remained attached to the previous, which enjoys its agenda climax.

\subsection{Influence of Agenda Sponsoring on Agenda Setting Transition}

Studies have argued front $[8,13,14,16]$ and back [17] on 'where does agenda-setting of an issue originate'. Having established that the power to set agenda is not a monopoly of the media but rather a reflection of media-public reciprocal influence, it is necessary to justify how agenda are sometimes sponsored to cause agenda shift. In Nigeria, influential people including politicians, parties and groups grant the media audience whenever they want to set agenda on issue as a form of attention diversion from real issue at the moment. Since their views make news, and the media benefit from their economic dominance through advertising charges raise their voices in the media above others; their voices become louder and the issue they emphasise in the media becomes a new agenda.

Could this have constituted agenda shift between boko haram saga and Ebola case? No empirical justification to substantiate that the media attention on Ebola issue was apolitical. However, information surplus in relation to scarcity of attentions induces the struggle to influence the agenda-setting function of the media. The competition for the limited attention as a tenet for agenda-setting delineates the origin and the routes through which an issue become prioritised whether through natural cause or artificial generation and sponsoring of issue for the purpose of attention diversion. Both routes use media to facilitate the spread of the issue in order to ensure that public interest and attention are won. The relationship between them encourages that an issue may be stripped off the saliency it enjoys as a result of the importance of another issue to the public or actions of influential individual and groups.

\section{Research Methodology}

Media reports on Boko-Haram insurgency and Ebola issues in two of the most popular daily newspapers in Nigeria (The Sun and The Guardian) were content analysed. The two newspapers selected for the study had extensive coverage of both the EVD outbreak and Boko-Haram insurgency. The analysis covered seven months; a month before and after Ebola rampage in Nigeria (June to December, 2014). Three major variables are used as tools to establish how the media saliency is shifted from an issue that enjoys media agenda to another. The variables are: a) Number of stories published on either of the issues at interval within the time lag; b) News page: what fraction of the publications on each issue makes front-page news since the front-page story is considered the most salient story of an edition; and c) Newshole: what fraction of the publication on each issue is given better treatment in term of space allotted. Each of the variables is quantitatively analysed and represented on line graphs to show the relationship in term of the saliency shift between the two competing issues.

\section{Findings and discussion}

Cross examination of how frequent the newspapers feature each of the issues gives impression on which of the issues received more media attention than the other at a time within the interval of the study. The frequency of an issue in newspapers in relation to the page in which it frequently appears in newspaper; and the proportion of space it often occupies, which dictated how in-depth the issue is treated are tantamount to the degree of saliency such issue enjoys and the pattern of saliency shift that is likely to occur when competing with other issues that compel lower, similar or higher media attention. The shift in the media saliency between Boko Haram insurgency and Ebola outbreak were measure at a time when both issue were burning to chronologically measure the change in the newspaper coverage of the issues. 
Table 1. Frequency of Published Stories in each of the Issues per Month

\begin{tabular}{|c|c|c|}
\hline & \multicolumn{2}{|c|}{ No of Stories Published by two newspapers per Month } \\
\hline Month (2014) & Boko Haram Stories & Ebola Stories \\
\hline June & 78 & 5 \\
\hline July & 64 & 78 \\
\hline August & 48 & 199 \\
\hline September & 46 & 194 \\
\hline October & 52 & 171 \\
\hline November & 73 & 134 \\
\hline December & 82 & 59 \\
\hline Total & 443 & 840 \\
\hline
\end{tabular}

Despite that Boko Hara insurgency had been enjoying media attention long before Ebola broke out, the table above shows that there is inverse relationship between the media attention given to the issues; as the outbreak broke out, there was significant decrease in the proportion of news stories on the insurgency between June and August. The relationship changed to direct in September; both having less media coverage than before (perhaps some other issues compelled media attention). Return-to-scale set in and returned the relationship back to inverse proportion between October and December but rather in favour of Boko Haram insurgency.

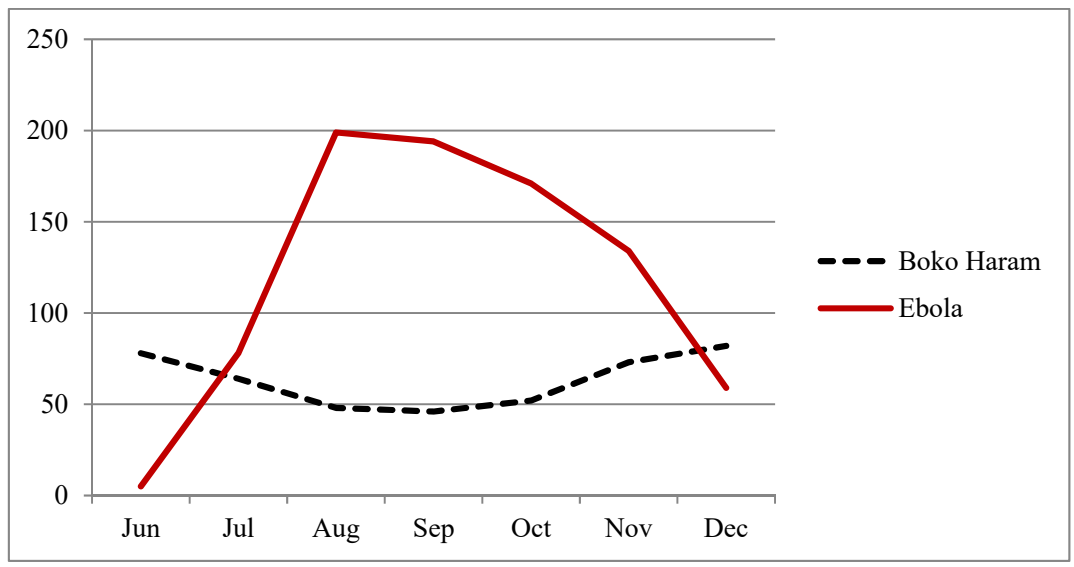

Fig. 1. Line Graph Showing Relationship between the Issues in Term of Number of Stories

Going by the overall attention given to the issues in both newspapers, more than three-quarter of 1103 stories on both issues was centred on Ebola. This shows that Ebola received more media coverage than Boko-Haram. The frequency of occurrence of Ebola news in the newspapers sent signal to the audience on how important the issue. It also justified what constitute public discussion since the issue media report frequently is relative to what becomes public agenda.

$$
\frac{840(\text { Total Ebola stories reported })}{7(\text { Months }) \times 2(\text { Sampled newspapers })}=60(\text { Average Ebola News stories per newspaper per month })
$$

This implies that an average of two news stories was published in each Nigerian newspaper per day within the period under study (See (1)). Contrarily, an average of a news story on Boko Haram insurgency was published in each of Nigerian newspaper per day (See (2)). This signifies the intensity of each of the issues and the equivalent attention that the media attached to each. 


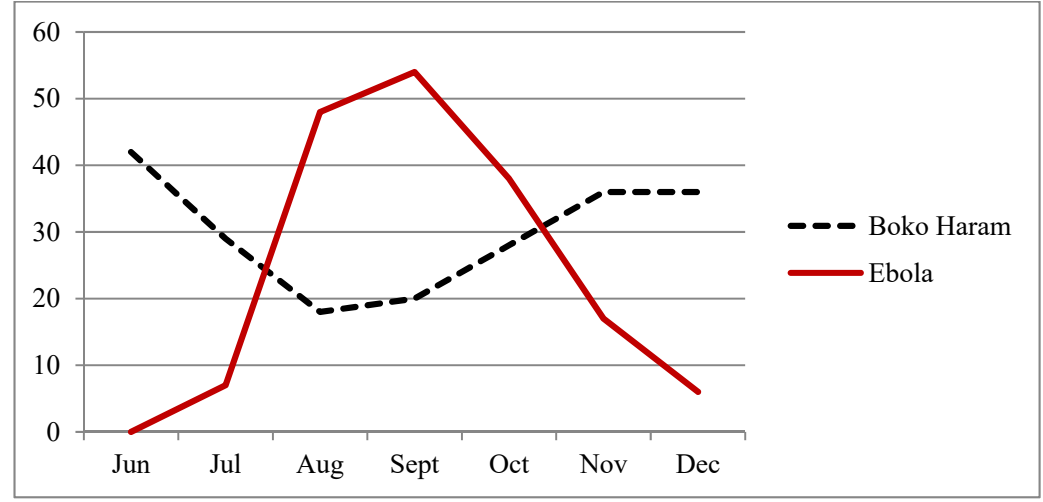

Fig. 2. Line Graph Showing Relationship between the Issues in Term of Front-page Advantage

The page on which a story appear and the amount of space it occupies in the newspaper are important criteria for measuring how important the story. Newspapers usually dedicate the front page to the most important news of the day while other stories of lesser importance are buried inside the newspapers. The front-page stories are regarded as attention catcher as well as Unique Selling Proposition for the edition in addition to its agenda setting function. As the newspaper started given Ebola stories attention on the front page in July, that of Boko-haram started falling until both get to equilibrium towards July ending. The fact that both enjoy return to scale at different periods (Boko Haram in midAugust and Ebola in mid-September) and also in opposite direction is an indication that the competitiveness for saliency between the issues is keen. It is also an indication that the shift in the saliency from Boko Haram to Ebola is neither absolute nor continuous (See Fig.2). The similar relationship was also established in the amount of space allotted to stories. Stories that are allotted a minimum of half page are considered detail and more important than those with less space (See Fig. 3)

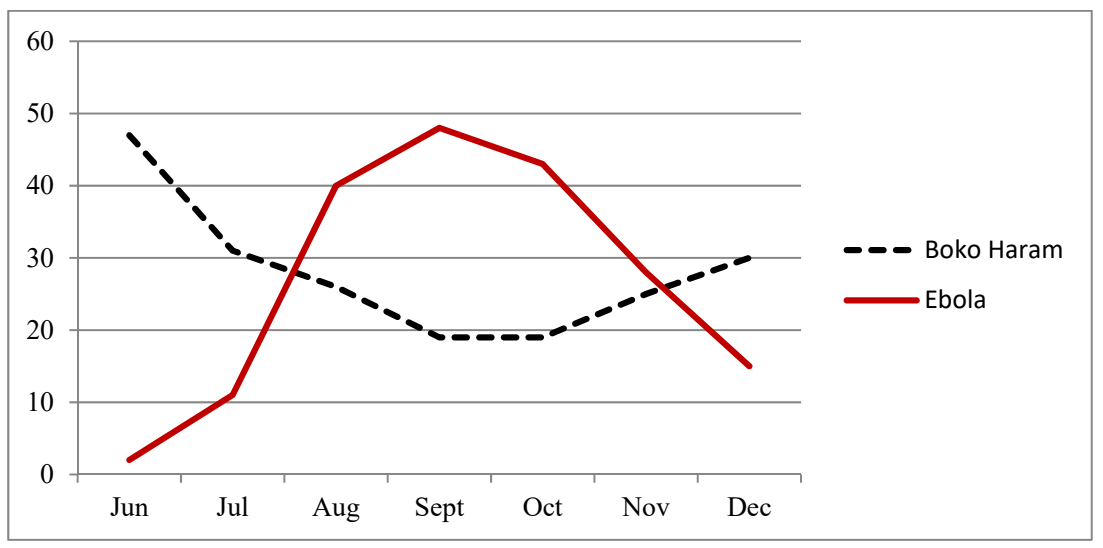

Fig. 3. Frequency of Issue of Focus in Relation to the Space Allotted in the Newspaper

\section{Conclusion}

Newspapers' attention was not shifted at once from Boko-Haram to Ebola despite that Ebola issue was then health emergency of international concern. The media agenda was gradually transferred from the issue that was enjoying the media attention to the new issue considered more important. EVD outbreak did not totally fade away Boko Haram insurgency; though its importance at first caused a major reduction in the salience the insurgency enjoyed and consequently brought EVD issue to limelight. It diverted higher proportion of public attentions away from Boko Haram insurgency, within its shot lifespan and the media agenda return to the latter, which had enjoyed long period of uninterrupted media agenda. The return of media saliency back to the insurgency explains the part play by issue prominence in the media preference of issue upon which agenda is set. 


\section{References}

1. L.A. Adelakun, Mass Communication and Journalism, 4, 193 (2014).

2. C.D. Vinson, Making the News: Politics, the Media, and Agenda Setting. Public Opinion Quarterly, 78(3), 761 (2014).

3. A.E. Boydstun, Making the news: Politics, the media, and agenda setting. University of Chicago Press (2013).

4. J.A. Martin, Making the news: Politics, the media, and agenda setting. Journalism, 16(2), 298-299 (2015).

5. L.K. Mustapha, Agenda-setting Theory: A Reflective and Visionary Analysis, in Critique and Application of Communication Theories, N.T. Ekeanyanwu, S.N. Ngoa, and I.A. Sobowale, Editors., Convenant University Press: Ota, Ogun State. 105-132(2012).

6. R. Coleman et al., Agenda setting. The handbook of journalism studies, 147-160 (2009).

7. P.A. Curtin,. Journal of Public Relations Research, 11, 1 (1999)..

8. $\quad$ P.A. Shaw et al,. Int. J. Public Opin. Res, 11, 1 (1999).

9. P. Bantimaroudis, S. Zyglidopoulos, and P.C. Symeou, J. com, 60, 4 (2010).

10. M.W. Ragas, and M.S. Roberts, Journalism \& Mass Communication Quarterly, 86, 1 (2009).

11. M. Besiou, M.L. Hunter, and L.N. Van Wassenhove, A Web of Watchdogs: Stakeholder Media Networks and Agenda-Setting in Response to Corporate Initiatives. J. Bus. Ethics, 118, 4 (2013).

12. S.H. Kim, D.A. Scheufele, and J. Shanahan,. Journalism \& mass communication quarterly, 79, 1 (2002).

13. S. Kiousis, and M. McCombs,. Communication Research, 31, 1 (2004).

14. S.J. Moon., Communication Research, 40, 5, (2013).

15. R. Vliegenthart, and S. Walgrave,. Party Politics, 17, 3 (2011).

16. U. Nwanne,. Global Journal of Medical Research, 14, (2014).

17. G. Thesen, Political Agenda Setting as Mediatized Politics? Media-Politics Interactions from a Party and Issue Competition PerspectiveInt. J. Press/Polit, 19, 2 (2014). 